
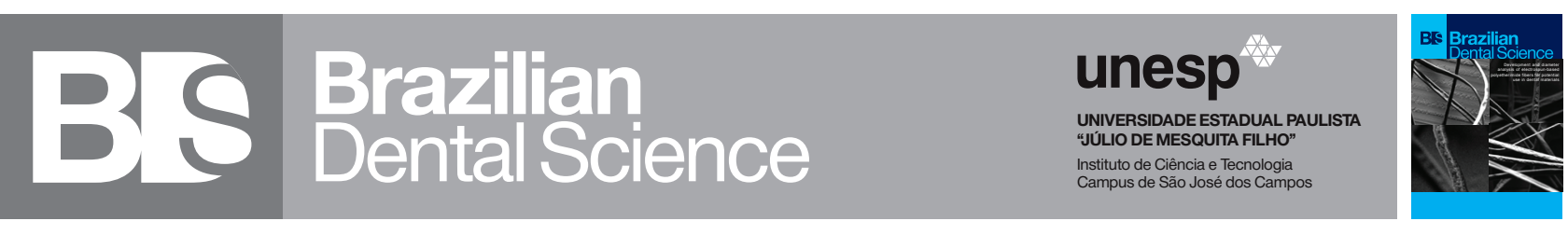

\title{
The Effect of Mouthrinses on Surface Roughness of Two Nanohybrid Resin Composites
}

Os efeitos dos enxaguatórios bucais na rugosidade superficial de duas resinas compostas nano-hibridas

Emre YILMAZ ${ }^{1}$, Arzu MUJDECI ${ }^{1}$

1 - Ankara University Faculty of Dentistry, Department of Restorative Dentistry, Ankara, Turkey.

\section{ABSTRACT}

Objective: The aim of this study was to evaluate the effect of four different mouthrinses on the surface roughness of two nanohybrid resin composites. Material and Methods: Fifty samples were prepared for each of the resin composites $(2 \times 8 \mathrm{~mm})$ and a profilometer was used to determine the initial surface roughness (Ra) of each sample. Then, they were divided into 5 subgroups $(n=10)$, and exposed to the following mouthrinses $\left(12 \mathrm{~h}, 37^{\circ} \mathrm{C}\right)$ : containing alcohol and essential oils; alcohol and chlorhexidine; alcohol-free and essential oils; alcohol free and cetil prydinium chlorite; or distilled water (control). The surface roughness of each sample was measured again. Statistical analyses of the data were performed via two-way ANOVA and Bonferroni tests. Results: Overall, statistically significant differences were not found between the resin composites ( $p>0.05$ ), but significant differences were found among the mouthrinses $(\mathrm{p}<0.05)$. Interactions between the mouthrinses and the resin composites was statistically significant $(p<0.05)$. Both of the resin composites had the highest surface roughness after exposure to mouthrinse with alcohol and essential oils ( $\mathrm{p}<$ 0.05), followed by mouthrinse with alcohol and chlorhexidine. Both alcohol-free mouthrinses caused surface roughness either similar to distilled water ( $p>0.05)$ or lower than distilled water $(p<0.05)$ on the nanohybrid resin composites used. Conclusion: The mouthrinses affected the surface roughness of the resin composites in different ways. This was dependent on mouthrinse contents and the chemical structure of the resin composites. Alcohol-containing mouthrinses caused the most changes in the surface roughness of both resin composites.

\section{KEYWORDS}

Alcohol; Chlorhexidine; Composite resin; Essential oil; Roughness.

\section{RESUMO}

Objetivo: O objetivo deste estudo foi avaliar o efeito de quatro diferentes enxaguatórios bucais sobre a rugosidade superficial de duas resinas compostas nano-híbridas. Material e Métodos: Cinquenta amostras foram preparadas para cada uma das resinas compostas $(2 \times 8 \mathrm{~mm})$ e um perfilômetro foi utilizado para determinar a rugosidade superficial inicial (Ra) de cada amostra. Em seguida, foram divididos em 5 subgrupos $(n=10)$ e expostos aos seguintes enxaguatórios (12h, $\left.37^{\circ} \mathrm{C}\right)$ : contendo álcool e óleos essenciais; álcool e clorexidina; Óleos sem álcool e essenciais; sem álcool e cloreto de cetilpridínio; ou água destilada (controle). A rugosidade da superfície de cada amostra foi medida novamente. As análises estatísticas dos dados foram realizadas por meio de ANOVA de dois fatores e testes de Bonferroni. Resultados: No geral, não foram encontradas diferenças estatisticamente significativas entre as resinas compostas ( $p>0,05)$, mas diferenças significativas foram encontradas entre os enxaguatórios bucais ( $\mathrm{p}<0,05)$. As interações entre os enxaguatórios bucais e as resinas compostas foram estatisticamente significativas ( $\mathrm{p}<0,05)$. Ambas as resinas compostas apresentaram maior rugosidade superficial após exposição ao enxaguatório bucal com álcool e óleos essenciais ( $p$ $<0,05$ ), seguido do enxaguatório com álcool e clorexidina. Ambos os enxaguatórios bucais sem álcool causaram rugosidade superficial semelhante à da água destilada ( $\mathrm{p}>$ $0,05$ ) ou menor do que a água destilada ( $p<0,05)$ nas resinas compostas nano-híbridas usadas. Conclusão: Os enxaguatórios bucais afetaram a rugosidade superficial das resinas compostas de diferentes maneiras. Isso dependia do conteúdo do enxaguatório bucal e da estrutura química dos compósitos de resina. Os enxaguatórios bucais contendo álcool causaram as maiores alterações na rugosidade superficial de ambas as resinas compostas.

\section{PALAVRAS-CHAVE}

Alcool; Clorexidina; Resina composta; Oléo essencial; Rugosidade. 


\section{INTRODUCTION}

$\mathrm{R}$ estorative materials used in dentistry should be able to withstand chemical and mechanical effects in the oral environment for prolonged periods of time [1]. A smooth surface not only provides aesthetic appear, but also prevents plaque retention and discoloration. In addition, a smooth surface reduces the wear rate by lowering coefficient of friction and increases clinical success of the material [2].

Nanofil and nanohybrid resins were introduced along with the development of nanotechnology in the field of restorative dentistry [3]. Nanohybrid resin composites contain 0.01$0.04 \mathrm{~nm}$ sized and clustered agglomerate fillers that may lead to increased filler content better surface smoothness, increased wear resistance and gloss retention [2]. Therefore, by virtue of their esthetic properties, nanocomposites are recommended to be used in both anterior and posterior restorations [3].

Mouthrinses used for oral hygiene can cause degradation of the resin composite surface because of their ingredients, such as alcohol, detergent, emulsifier and organic acid [4].

Antimicrobial mouthrinses are chemical agents used to maintain oral hygiene; they typically contain active ingredients such as chlorhexidine gluconate (CHX), cetil prydinium chlorite (CPC), or essential oils [6]. CHX is a cationic bis-biguanide that has wide spectrum antimicrobial effects that is also a gold standard for reducing plaque and gingivitis [6]. CPC is a cationic agent that has antiseptic and wide spectrum antimicrobial effects [7]. Essential oils (also known as phenolics) have wide spectrum antibacterial/antigingivitis effects. Mouthrinses containing essential oils often contain thymol, menthol, eucalyptol, and methyl salicylate [8].

The effects of mouthrinses on color, microhardness, microleakage, water absorption, and solubility of resin composites have been investigated in many studies, but there are few studies evaluating the effect of mouthrinses on the surface roughness of resin composites [912]. These few studies mostly have concentrated on microhybrid, hybrid, or nanofilled resin composites, and have differing conclusions. Silva et al. [9] have reported that a mouthrinse containing ethanol affected the surface roughness of nanofiller, microfiller, and microhybrid resin composites. Likewise, Festuccia et al. [10] have stated higher surface roughness with an alcohol-containing mouthrinse than alcoholfree mouthrinses. On the other hand, Trauth et al. [11] have reported that an alcohol-free mouthrinse, an alcohol-containing mouthrinse, and a control mouthrinse caused similar surface roughness values for nanofilled resin composites. Similar to that study, Urbano et al. [12] have explained that the high alcohol concentration of a mouthrinse was not sufficient to increase the surface roughness of a nanofilled composite.

Overall, there are limited knowledge regarding the effect of mouthrinses on the surface roughness of nanohybrid resin composites, which have many physical, chemical, and aesthetic advantages. It has been reported that ethanolcontaining mouthrinses affect the surface roughness of nanohybrid resin composites $[13,14]$. Since nanohybrid resin composites are routinely used as restorative materials, and because the use of mouthrinses is becoming more common, it is important to evaluate the effect of mouthrinses (which have different contents, active ingredients, $\mathrm{pH}$ and alcohol concentrations) on nanohybrid resin composites. Therefore, the aim of this study is to evaluate the effect of four different mouthrinses on the surface roughness of two nanohybrid resin composites. The investigated first null hypothesis was that the mouthrinses having different active ingredients would not affect the surface roughness of resin composites. The second hypothesis was that the composition of resin composites would have no differences on the surface roughness of the material. 
Table I - Resin composites used in this study

\begin{tabular}{|c|c|c|c|}
\hline $\begin{array}{c}\text { RESIN } \\
\text { COMPOSITES }\end{array}$ & TYPE & MONOMERS & INGREDIENTS \\
\hline $\begin{array}{c}\text { Clearfil Majesty } \\
\text { Esthetic (Kuraray } \\
\text { Medical INC, } \\
\text { Okuyama, JA- } \\
\text { PAN) }\end{array}$ & Nanohybrid & $\begin{array}{l}\text { Bis-GMA } \\
\text { Hydrophobic } \\
\text { aromatic dime- } \\
\text { thacrylate }\end{array}$ & $\begin{array}{c}\text { Unsilanized barium glass filler } \\
\text { (average particle size } 0.7 \mu \mathrm{m} \text { ) } \\
\text { Organic fillers prepolymerized } \\
\text { nanofillers } \\
\text { dl-camphorquinone } \\
\text { Organic filler (load } 78 \% \text { by } \\
\text { weight, } 66 \% \text { by volume) } \\
\text { Inorganic filler (load } 40 \% \text { by } \\
\text { volume) }\end{array}$ \\
\hline $\begin{array}{l}\text { Filtek Z550 (3M } \\
\text { ESPE, StPaul, MN, } \\
\text { USA) }\end{array}$ & Nanohybrid & $\begin{array}{c}\text { Bis-GMA } \\
\text { UDMA } \\
\text { Bis-EMA } \\
\text { TEGMA } \\
\text { PEGDMA }\end{array}$ & $\begin{array}{c}\text { Surface-modified zirconia/ } \\
\text { silica fillers } 3.000 \mathrm{~nm} \text { ( } 3 \mu \mathrm{m} \\
\text { or less) } \\
\text { Non-agglomerated/non-ag- } \\
\text { gregated surface-modified } \\
\text { silica particles } 20 \mathrm{~nm} \\
\text { Filler load } 82 \% \text { by weight, } 68 \% \\
\text { by volume }\end{array}$ \\
\hline
\end{tabular}

\section{MATERIAL AND METHODS}

In this study, two nanohybrid resin composites and four different mouthrinses were used. These are listed in Table I and Table II, respectively.

Table II - The mouthrinses used in this study

\begin{tabular}{|c|c|c|c|}
\hline MOUTHRINSES & TYPE & INGREDIENTS & pH \\
\hline $\begin{array}{c}\text { Listerine Cool Mint } \\
\text { (Johnson \& Johnson, } \\
\text { New Brunswick, NJ, } \\
\text { USA) }\end{array}$ & $\begin{array}{l}\text { Alcohol and } \\
\text { essential } \\
\text { oils }\end{array}$ & $\begin{array}{l}\text { Thymol, eucalyptol, methyl } \\
\text { salicylate, menthol, water, } \\
\text { sorbitol solution, alcohol (21.6\%), } \\
\text { poloxamer } 407 \text {, benzoic acid, } \\
\text { mint extract, sodium saccharin, } \\
\text { sodium benzoate }\end{array}$ & 3.92 \\
\hline $\begin{array}{l}\text { Oral-B Alcohol-Free } \\
\text { (Procter \& Gamble,- } \\
\text { Cincinnati, Ohio, USA) }\end{array}$ & $\begin{array}{l}\text { Alcohol-free } \\
\text { and cetyl } \\
\text { pyridinium } \\
\text { chloride }\end{array}$ & $\begin{array}{l}\text { Water, glycerin, PEG-40, hydro- } \\
\text { genated castor oil, methylpa- } \\
\text { raben, cetyl pyridinium chloride } \\
\text { monohydrate }(0.053 \%) \text {, aroma } \\
\text { sodium fluoride }(0.050 \%) \text {, sodium } \\
\text { saccharin, sodium benzoate, } \\
\text { propylparaben }\end{array}$ & 5.76 \\
\hline $\begin{array}{c}\text { Peridex } \\
\text { (St.Paul, MN,USA) }\end{array}$ & $\begin{array}{l}\text { Alcohol and } \\
\text { chlorhexi- } \\
\text { dine }\end{array}$ & $\begin{array}{l}0.12 \% \text { chlorhexidine gluconate, } \\
\text { water,\%11.6 alcohol, PEG-40 sor- } \\
\text { bitan dilisostearate, flavor, sodium } \\
\text { saccharin, FD\&C Blue No.1 Dye. }\end{array}$ & 5.5 \\
\hline $\begin{array}{c}\text { Listerine Zero } \\
\text { (Johnson \& Johnson, } \\
\text { New Brunswick, NJ, } \\
\text { USA) }\end{array}$ & $\begin{array}{l}\text { Alcohol-free } \\
\text { and essen- } \\
\text { tial oils }\end{array}$ & $\begin{array}{l}\text { Thymol, eucalyptol, methyl sali- } \\
\text { cylate, sodium fluoride }(0.02 \%), \\
\text { water, sorbitol solution, propylene } \\
\text { glycol, poloxamer } 407, \text { sodium } \\
\text { benzoate, sodium lauryl sulfate, } \\
\text { sodium saccharin, disodium } \\
\text { phosphate, sucralose }\end{array}$ & 4.41 \\
\hline Distilled Water & & & 5.88 \\
\hline
\end{tabular}

\section{Preparation of Specimens}

The sample size to be used in the study was determined using a power analysis program (G * Power, Heinrich Heine University, Düsseldorf, Germany). With a $0.5 \%$ confidence interval, the total sample size was determined to be 100. Fifty samples of each nanohybrid resin composite were inserted as a single increment into a Teflon mold with an $8 \mathrm{~mm}$ internal diameter and $2 \mathrm{~mm}$ height. Two polyester strips (Kerr Hawe, Bioggio, Switzerland) were positioned above and below the mold, and a glass slide was pushed down on the top surface of each specimen with finger pressure to remove excess material. After the glass slide was removed, the specimens were polymerized with an LED curing light (Elipar Freelight II, 3M ESPE, St. Paul, MN, USA) with $1200 \mathrm{~mW} / \mathrm{cm}^{2}$ of output power for 20 s. The curing light was monitored with a lightmeter (Curing Radiometer, Demetron Research, CT, USA). Then, the specimens were stored in distilled water at $37^{\circ} \mathrm{C}$ for 24 hours.

\section{Surface Roughness}

The initial surface roughness of the specimens (before mouthrinse exposure) was obtained using a profilometer device (Mahr M2 Profilometer, Mahr GmbH, Göttingen, GERMANY) with a scanning tip method (tip width: $0.5 \mu \mathrm{m}$, accuracy: $0.01 \mu \mathrm{m}$ ). The stylus was moved across the diameter of the central portion on the top-face of each sample three times, and the mean roughness parameter (Ra) for each specimen was recorded. The $\mathrm{Ra}$ parameter describes the overall roughness of a surface and can be defined as the arithmetical average value of all absolute distances of the rough- ness profile from the centre line within the measuring length [15].

\section{Use of Mouthrinses}

After the initial roughness measurements were taken, the specimens were randomly divided into 5 subgroups containing 10 specimens each and exposed to the following 
mouthrinses: with alcohol and essential oils; alcohol and CHX; alcohol-free and essential oils; alcohol free and CPC; or distilled water (control, no mouthrinse was used). Each subgroup were placed in vials with $20 \mathrm{ml}$ of one of the four mouthrinses or distilled water.

The specimens were kept in their respective solutions for 12 hours at $37^{\circ} \mathrm{C}$. The specimens in the mouthrinses were shaken for 10 seconds every hour to prevent the formation of a chemical equilibrium around the specimen surface [16]. After 12 hours, the specimens were removed from the solutions, washed with distilled water, and dried. Then, the surface roughness test was repeated as above, and recorded as 'after mouthrinse' exposure values. Roughness changes between the before and after mouthrinse exposure values were calculated, and the data were analyzed via two-way ANOVA and Bonferroni tests (SPSS 14.01). The level of significance was 0.05 .

\section{RESULTS}

The means and standard deviations of the differences in surface roughness values between the two nanohybrid resin composites before and after exposure to four different mouthrinses and distilled water are shown in Table III. A two-way ANOVA for different factors (resin composites, mouthrinses) and interactions of the factors are presented in Table IV.

Of the two main factors (mouthrinses, resin composites) evaluated in this study, there were no significant differences between the surface roughness of the resin composites ( $p>$ 0.05 ), but there were significant differences among the mouthrinses $(\mathrm{p}<0.05)$ (Table IV).

In addition, interactions between the mouthrinses and the resin composites was found statistically significant $(\mathrm{p}<0.05)$ (Table IV). The surface roughness of both resin composites was affected most by the mouthrinse with alcohol and essential oils, followed by the mouthrinse with alcohol and CHX. The Clearfil Majesty Esthetic resin composite had the lowest surface roughness values when exposed to the alcoholfree mouthrinses $(p<0.05)$. The Filtek Z550 resin composite had no significant differences in surface roughness caused by the distilled water or the two alcohol-free mouthrinses $(\mathrm{p}<0.05)$ (Table III).

When the effects of the mouthrinses on the two nanohybrid resin composites were compared, it was determined that the mouthrinse with alcohol and essential oils caused the most surface roughness for the Filtek Z550 resin composite, while the mouthrinse with alcohol and CHX caused the most surface roughness on the Clearfil Majesty Esthetic resin composite. In addition, it was found that distilled water caused significantly more surface roughness on the Clearfil Majesty Esthetic resin composite than on the Filtek Z550 resin composite $(\mathrm{p}<$ 0.05) (Table III).

Table III - Surface roughness values $\left(R_{a}\right)$

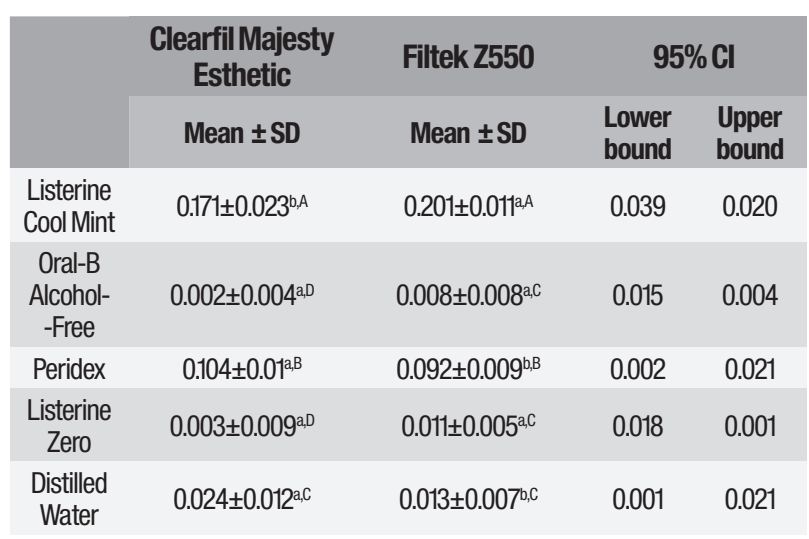

* The effect of "Composite" and "Mouthrinse" groups on Ra values were calculated using two-way analysis of variance (ANOVA). Simple effect analysis with Bonferroni adjustment was used to resolve any significant interaction terms. Different lowercase letters in rows and different uppercase letters in columns are statistically difference $(p<0.05)$. 
Table IV - Tests of between subjects-effects

\begin{tabular}{|cccc|}
\hline Source & df & F & p-value \\
\hline Resin composites & 1 & 3.703 & 0.057 \\
\hline Mouthrinses & 4 & 1033.508 & $<0.001$ \\
\hline Resin composites * Mouthrinses & 4 & 11.916 & $<0.001$ \\
\hline Error & 90 & & \\
\hline Total & 100 & & \\
\hline
\end{tabular}

* R Squared: 0,979 (Adjusted R Squared: 0,977).

*df:degrees of freedom.

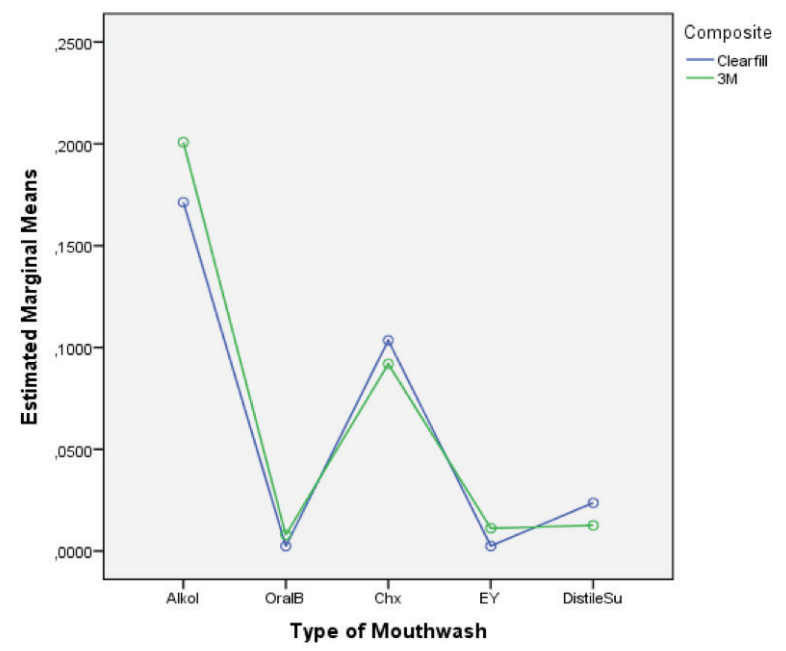

Figure 1- Estimated marginal means of the effect of Composite and Mouthrinse groups on Ra values.

\section{DISCUSSION}

This in vitro study was conducted to evaluate the effect of four different mouthrinses on the surface roughness of two nanohybrid resin composites. It was found that alcohol-containing mouthrinse caused more surface roughness that chlorhexidine, CPC-containing and alcohol-free mouthrinses and distilled water.

It is known that active ingredients, $\mathrm{pH}$, and alcohol contents of mouthrinses affect the surface properties of resin composites [17]. Therefore, this study included mouthrinses that are commonly used, and that had four different compositions (i.e., containing alcohol and essential oils, alcohol and CHX, alcohol-free and CPC, alcohol-free and essential oils).

Surface roughness is closely related to finishing and polishing techniques. During the finishing and polishing processes, some areas of the composite may be removed from the organic matrix, and filler particles and glass particles that break away from these areas may cause pits and rough areas on the surface [18]. In addition, the polishing process increases the surface area and can create surface irregularities, allowing solutions to enter the polymeric matrix, causing destruction of the resin [19]. Therefore, as in other studies $[18,20]$, in this study, the surface of the resin composite samples was not finished/ polished in order to prevent the effect of the finishing/polishing process on the results [21]. Herein, the surface roughness of the samples polymerized against a polyester strip was determined.

In this study, the specimens were kept in distilled water for 24 hours after polymerization. This was done so that any unreacted components would be removed from the resin composite, and to confirm that the polymerization would be complete after light-cure. Resin composite specimens were kept in the mouthrinses for 12 hours; this was determined to be equivalent to one year of mouthrinse usage for two minutes a day [22].

Surface roughness is considered to be a two-dimensional parameter of the material surface, and it is measured by atomic force microscopy or by a profilometer device. Atomic force microscopy measurements are performed in contact with the sample surface (contact mode), and therefore, this technique can cause damage to hard and glassy surfaces, as well as soft surfaces, such as polymer/biological samples [23]. In this study, a profilometer was used to determine the average surface roughness values (Ra) of the composites. This method was chosen because it measures the surface roughness of composite discs effectively and correctly, and because it is easy to use [24].

The study hypothesis which was that 
mouthrinses with different active ingredients would not affect the surface roughness of the nanohybrid resin composites was partially accepted, as the surface roughness of the dimethacrylate-based nanohybrid resin composites was affected differently by the four mouthrinses used. The mouthrinse containing alcohol and essential oils increased the most the surface roughness of the nanohybrid resin composites tested. Second was the mouthrinse containing alcohol and CHX, followed by the mouthrinse containing alcohol and essential oils. The non-alcoholic mouthrinses containing CPC and containing essential oils had the least effect on the surface roughness of the nanohybrid composites; further these two mouthrinses produced surface roughness values similar to or less than those caused by distilled water. The current result showing that mouthrinses containing alcohol caused increased surface roughness of the two nanohybrid resin composites more than alcohol-free mouthrinses is compatible with the results of Silva et al [9]. This result may be due to the fact that alcohol has a plasticizing effect [25]. It has been reported that the surface of Bis-GMA based materials softens when exposed to solvents having solubility parameters between $1.82-2.97 \times 10^{-4}\left(\mathrm{~J} / \mathrm{m}^{3}\right)^{1 / 2}$. Ethanol is an organic solvent with a solubility parameter of $2.62 \times 10^{-4}\left(\mathrm{~J} / \mathrm{m}^{3}\right) 1 / 2$ which is close to the solubility parameter of dimethacrylates. Therefore, the effect of ethanol on the solubility of dimethacrylate-based resin composites is not surprising [26] as it has the ability to penetrate and affect the polymeric structure [27]. After ethanol penetrates the resin composite, it causes the material to swell, thus breaking the polymeric matrix chains and reducing the cross-linking density [28]. In addition, ethanol stretches the bonds in the inorganic component by creating tensile stresses in the resin matrixfiller interface, and it facilitates the removal of filler particles by increasing the frictional forces between matrix-filler, leading to increased roughness [29]. Penugonda et al. [30] have reported that the surface roughness of resin composites is directly related to the alcohol percentage of mouthrinses. The alcohol content of the mouthrinse containing alcohol and essential oils used in the present study was quite high $(21.6 \%)$, and it caused the most surface roughness on the two resin composites used. This can be due to the swelling of the polymeric matrix and leaching of unreacted monomers and oligomers, which also causes increased surface roughness [31]. Almeida et al. [32] have also reported that nanofilled and hybrid resin composites presented higher sorption and solubility with mouthrinses containing high alcohol levels. In the present study, the other mouthrinse containing low alcohol level (11.6\%) and CHX also significantly increased the surface roughness of both resin composites, but this was lower than that of the mouthrinse containing high alcohol and essential oils.

The mouthrinse containing alcohol and essential oils had the lowest $\mathrm{pH}(\mathrm{pH}=3.92)$ in addition to the highest alcohol level (21.6\%) among the mouthrinses used, which is most likely why it produced the highest surface roughness values of both resin composites tested. It has been reported that mouthrinses [11] and other solutions [33] with low $\mathrm{pH}$ and high alcohol levels cause composites to soften by affecting their surface integrity and some other mechanical properties $[11,33]$. Low $\mathrm{pH}$ causes loss of cations and structural ions, and creates erosion on filler surface, which leads to the separation of fillers from the composite, and therefore, causing a rough surface [34]. In addition, it has been reported that mouthrinses with low $\mathrm{pH}$ cause increased water sorption and solubility of resin composites [17]. Morever, the low $\mathrm{pH}$ of the mouthrinses causes the catalysis of the ester groups from the dimethacrylate monomers (Bis-GMA, TEGDMA, Bis-EMA, UDMA) in the polymeric matrix structure of resin composites. These ester groups can form 
alcohol and carboxylic acid molecules, leading to further $\mathrm{pH}$ reduction in the composite resins, thereby accelerating composite destruction $[9,34]$.

Active ingredients of mouthrinses play a role in the surface roughness of resin surfaces [17]. Essential oils (including eucalyptol, thymol, menthol, and methyl salicylate) as active ingredient in some mouthrinses are potential sources of erosion/destruction of acrylic and thermoplastic resins [35]. Therefore, essential oils active ingredient in addition to high alcohol content and low $\mathrm{pH}$ of the mouthrinse containing alcohol and essential oils may also have played a role in the increased surface roughness of the nanohybrid resin composites used in this study.

In the present study, $\mathrm{pH}$ of the mouthrinses did not have the same effect on the surface roughness. Despite their acidic nature, the mouthrinse containing alcohol (11.6\%) and $\mathrm{CHX}(\mathrm{pH}=5.5)$ caused the more roughness than the mouthrinse with alcohol-free and essential oils $(\mathrm{pH}=4.41)$ on both resin composites used. The higher surface roughness may be due to the fact that alcohol content of the first mouthrinse. In addition, CHX gluconate as an active ingredient of the first mouthrinse could also be responsible from this result. CHX has a high ionic concentration, which may have caused the release of soluble components from the resin composites, increasing surface roughness [36]. Similar to the results of the current study, Abo El Naga and Yousef [31] have also reported increased surface roughness of resin composites exposed to mouthrinses containing CHX.

Again, despite its acidic $\mathrm{pH}(\mathrm{pH}=4.41)$ and its active ingredient of essential oils which have been reported to increase surface roughness of resin composites [35], the mouthrinse with alcohol-free and essential oils did not increase the surface roughness of the two nanohybrid resin composites compared to the distilled water control. The reason for this result is not known.
However, Yap et al. [37] have also reported that nano-filled and minifil resin composites have been affected similarly by distilled water and food solvents with different $\mathrm{pH}$.

Both alcohol-free mouthrinses (containing CPC and containing essential oils) caused less surface roughness than did distilled water for the Clearfil Majesty Esthetic resin composite, while these mouthrinses displayed similar surface roughness to distilled water for the Filtek Z550 resin composite. Similarly, Davalloo et al. [38] have reported similar surface hardness of microhybrid resin composites exposed to distilled water and two alcohol-free mouthrinses containing CPC. Alcohol-free nature of the two mouthrinses are thought to contribute to this result. It is known that resin composites kept in a mixture of ethanol and water exhibit more solubility than those kept in water alone. The solubility parameter of water $\left[4.80 \times 10^{-4}(\mathrm{~J} /\right.$ $\left.\mathrm{m}^{3}\right)^{1 / 2}$ ] is different from the solubility parameter of dimethacrylate-based resins, and therefore, water can be thought of as less soluble [39]. To this end, Geurtsen et al. [40] have explained that mouthrinses contain mostly water, and therefore, the effect of mouthrinses on the hardness of resin composites should be similar to that of distilled water. The present study result obtained with the alcohol-free mouthrinses may also be related to the water content of the mouthrinses in addition to their alcohol-free nature.

Concerning the effect of mouthrinses on surface roughness of resin composites, there are also other studies which have revealed differing results. For instance, Trauth et al. [11] have reported that alcohol-containing $(6 \%, 8.7 \%$, $14.5 \%)$ and alcohol-free mouthrinses have caused similar surface roughness values on a nanofiller resin composite. Additionally, Urbano et al. [12] have revealed that the mouthrinses used in their study (even those with high alcohol concentrations (21.6\%) did not break the crosslinking of the polymeric matrix, did 
not cause modifications on the material surface, and did not increase the surface roughness of a nanofiller resin composite. Since increased surface roughness has been reported to be directly related to the storage duration in mouthrinses/ solutions [22], the contradictory results between different studies may be a results of different storage times of the samples in mouthrinses. In the current study, the resin composite specimens were kept in the mouthrinses for 12 hours. However, Trauth et al. [11] have exposed their specimens to mouthrinse for only 1 minute twice a day, 5 days a week for 3 weeks, and Urbano et al. [12] have exposed their specimens to mouthrinse 1 minute every 12 hours for 30 days. Also, considering that mouthrinses do not remain in the mouth continuously for 12 hours and are used only 2 minutes on average, and as saliva has a protective effect, these mouthrinses may cause less roughness in daily use.

The effect of mouthrinses on the surface roughness of resin composites can vary depending on the composition of the resin composites as wall as the contents, $\mathrm{pH}$, and application times of the mouthrinses. It has been reported that different mouthrinses affect resin composites differently [10]. The second hypothesis of the current study, which indicated that the composition of resin composites used would have no differences in surface roughness, was rejected. The effect of mouthrinses on the surface roughness of the resin composites was material dependent, and there were significant interactions between the resin composites and the mouthrinses. The mouthrinse with alcohol and essential oils caused the most surface roughness on the Filtek Z550 resin composite, while the mouthrinse with alcohol and CHX caused the most on the Clearfil Majesty Esthetic resin composite. Although both of the composites used herein are nanohybrid in nature, they have differences in monomer structures and filler particle systems, which may have caused them to be affected differently by different mouthrinses. The Filtek Z550 resin composite used in this study contains Bis-GMA, Bis-EMA, UDMA, and PEGDMA, while Clearfil Majesty Esthetic consists of Bis-GMA and hydrophobic aromatic dimethacrylate. Further, the Filtek Z550 resin composite contains surface-modified zirconia silica with an average particle size of $<3 \mu \mathrm{m}$, non-agglomerated/aggregated $20 \mathrm{~nm}$ surface modified silica, and the filler load is $82 \%$ by weight. The Clearfil Majesty Esthetic consists of organic fillers as prepolymerized nanofillers with a size of $0.7 \mu \mathrm{m}(78 \% \mathrm{wt})$ and unsilanized inorganic barium glass fillers (40\% vol). As the two nanocomposites used in this study have different resin structures, this may be why the same mouthrinses caused different surface roughness values.

It is clinically important that restorative materials have smooth surface. Rough surfaces are associated with bacterial colonization, and they cause aesthetic concern, as they can affect the color and polish of the restorations (10). The acceptable threshold value of surface roughness is $0.2 \mu \mathrm{m}$. Surface roughness over $0.2 \mu \mathrm{m}$ increases bacterial adhesion and colonization on the surface of resin composites. Roughnesses $>0.3 \mu \mathrm{m}$ can be felt when the patient's lips or tongue come into contact with the restorative material (10). In the current study, the Filtek Z550 resin composite had a surface roughness of $0.2 \mu \mathrm{m}$ when exposed to the mouthrinse with alcohol and essential oils, but the roughness values obtained with the other mouthrinses were well below this limit on both resin composites.

Nowadays, aesthetics is becoming more important to patients. Therefore, the interaction of resin composites with mouthrinses, which are used frequently in oral hygiene procedures, has become an important issue. The current study revealed that different mouthrinses have different effects on the surface roughness of two nanohybrid resin composites. A mouthrinse containing alcohol and essential oils caused the most surface roughness, and a mouthrinse 
containing alcohol and CHX caused the secondmost roughness on the nanohybrid resin composites used in this study. Alcohol-free mouthrinses did not have any negative effects on the nanohybrid resin composites.

\section{CONCLUSION}

In conclusion, mouthrinses affected the surface roughness of nanohybrid resin composites in different ways, depending on their content, as well as on the chemical structure of the resin composites. Alcohol-containing mouthrinses increased the surface roughness of the resin composites. Both of the resin composites had the highest surface roughness after exposure to mouthrinse with alcohol and essential oils, followed by mouthrinse with alcohol and chlorhexidine. Alcohol-free mouthrinses did not cause any negative effects on the nanohybrid resin composites. Considering that mouthrinses do not remain in the mouth continuously for 12 hours and are used only 2 minutes on average, and as saliva has a protective effect, these mouthrinses may cause less roughness in daily use. Nevertheless, in order to have longlasting and aesthetically favorable nanohybrid resin composite restorations, which are highly aesthetic in terms of polishability, light transmittance, and wear resistance, it may be appropriate for patients having such restorations in their mouths to use low alcohol-containing and low-pH mouthrinses.

\section{REFERENCES}

1. Yanikoglu N, Duymus Z, Yilmaz B. Effects of different solutions on the hardness of composite resin materials. Dent Mater J. 2009;28(3):344-51.

2. Kakaboura A, Fragouli M, Rahiotis C, Silikas N. Evaluation of surface characteristics of dental composite using profilometry, scanning electron, atomic force microscopy and gloss-meter. J Mater Sci Mater Med. 2007;18(1): 155-63.

3. Bayne SC. Beginnings of the dental composite revolution. J Am Dent Assoc. 2013;144:880-4.

4. Demirci M, Tuncer S, Oztas E, Tekce N, Uysal O. A 4-year clinical evaluation of direct composite build-ups for space closure after orthodontic treatment. Clin Oral Investig. 2015;19:2187-99.
5. Colucci V,Dos Santos CD, Amaral FL, Corona SA. Influence of $\mathrm{NaHCO}$ powder on translucency of microfilled composite resin immersed in different mouthrinses. J Esthet Restor Dent 2009;21(4):242-8.

6. Moran JM. Home-use oral hygiene products: Mouthrinses. Periodontol. 2000 2008:48:42-53

7. Farah CS, Mclntosh L, McCullough MJ. Mouthwashes. Aust Prescr. 2009;32: $162-4$.

8. Ouhayoun JP.Penetrating the plaque biofilm: impact of essential oil mouthwash. J Clin Periodontol. 2003;30(5):10-2.

9. Silva EM, De Sá Rodrıgues Cu, Dias DA, Da Silva S, Amaral CM, Guimarães JG.. Effect of toothbrushing-mouthrinse-cycling on surface roughness and topography of nanofilled, microfilled, and microhybrid resin composites. Oper Dent. 2014;39(5):521-29.

10. Festuccia MSSC, Garcia LFR, CruvinelDR, Pires-De-Souza FCP.Color stability, surface roughness and microhardness of composites submitted to mouthrinsing action. J Appl Oral Sci.2012; 20(2):200-5.

11. Trauth KG, Godoi AP, Colucci V, Corona SA, Catirse AB. The influence of mouthrinses and simulated toothbrushing on the surface roughness of a nanofilled composite resin. Braz Oral Res. 2012;26(3):209-14.

12. Urbano CD, Abrahão ALS, Lancellotti AC, De Menezesoliveira MAH, Calabrez S, De Souza Gonçalves L. Effect of mouthrinses on the surface roughness of nanofilled composite. Braz Dent Sci. 2014;17(3):92-7.

13. Yofindra BM, Damiyanti M, Herda E. Effects of immersion in mouthwash for different durations and with different ethanol concentrations on the surface roughness of nanohybrid composite resin. IOP Conf. Series: Journal of Physics: Conf. Series. 2018;1073,032002. doi:10.1088/17426596/1073/3/032002

14. Armas-Vega A, Casanova-Obando P, Taboada-Alvear MF, Aldas-Ramirez JE, Montero-Oleas N, Viteri-Garcia A. Effect of mouthwashes on the integrity of composite resin and resin modified glass ionomer: In vitro study. J Clin Exp Dent. 2019;11(2):79-84.

15. Whitehead SA, Shearer AC, Watts DC, Wilson NH. Comparison of methods for measuring surface roughness of ceramic. J Oral Rehabil. 1995;22(6):42127.

16. Gurgan S, Yalcin Cakir F. The effect of three different mouthrinses on the surface hardness, gloss and colour change of bleached nano composite resins. Eur JProsthodont Restor Dent. 2008;16(3):104-8.

17. Yap AU, Tan BW, Tay LC, Chang KM, Loy TK, Mok BY. Effect of mouthrinses on microhardness and wear of composite and compomer restoratives. Oper Dent. 2003;28(6):740-46

18. Yap AUJ, Yap SH, Teo CK, Ng JJ. Finishing/polishing of composite and compomer restoratives: effectiveness of one-step systems. Oper Dent. 2004;29(3):275-9.

19. Barbosa SH,Zanata RL, Navarro MF, Nunes OB. Effect of different finishing and polishing techniques on the surface roughness of microfilled, hybrid and packable composite resins. Braz Dent J. 2005; 16(1):39-44.

20. Ergucu Z, Turkun LS. Surface roughness of novel resin composites polished with one-step systems. Oper Dent. 2007;32(2):185-92.

21. Cavalcanti AN, Mitsui FH, Ambrosano GM, Mathias P, Marchi GM. Effect of different mouthrinses on Knoop hardness of a restorative composite. Am J Dent. 2005:18(6):338-40.

22. Gurdal P, Akdeniz BG, Hakan Sen B. The effects of mouthrinses on microhardness and colour stability of aesthetic restorative materials. J Oral Rehabil. 2002;29(9):895-901. 
23. Blanchard CR. Atomic Force Microscopy. The Chemical Educator. 1996;(1):1-8.

24. Wan Bakar W, McIntyre J. Susceptibility of selected tooth-coloured dental materials to damage by common erosive acids. Aust Dent J. 2008;53(3):22634.

25. Sarret DC, Colletti DP, Peluso AR. The effects of alcoholic beverages on composite wear. Dent Mater. 2000;16(1):62-7.

26. Mckinney JE, Wu W. Relationship between subsurface damage and wear of dental restorative composites. J Dent Res. 1982;61(9):1083-8.

27. Yap AU, Tan SH, WeeSS, Lee CW, Lim EL, Zeng KY.Chemical degradation of composite restoratives. J Oral Rehabil. 2001;28(11):1015-21

28. Benetti AR, Peutzfeldt A, Asmussen E, Pallesen U, Franco EB. Influence of curing rate on softening in ethanol, degree of conversion, and wear of resin composite. Am J Dent. 2011;24(2):115-8.

29. Soderholm KJ. Degradation of glass filler in experimental composites. J Dent Res. 1981;60(11):1867-75.

30. Penugonda B, Settembrini L, Scherer W, Hitellmann E, Strassler H. Alcoholcontaining mouthwashes: Effect on composite hardness. J Clin Dent. 1994:5(2):60-2.

31. Abo El Naga A, Yousef M. Evaluation of different restorative materials after exposure to chlorhexidine. J Am Sci. 2012;8(8):628-31.

32. Almeida GS, Poskus LT, Guimarães JG, Da Silva EM. The effect of mouthrinses on salivary sorption, solubility and surface degradation of a nanofilled and a hybrid resin composite. Oper Dent. 2010;35(1):105-11.
33. Villalta P,Lu H, OkteZ, Garcia-Godoy F,Powers JM. Effects of staining and bleaching on color change of dental composite resins. J Prosthet Dent. 2006;95(2):137-42.

34. Gopfreich A. Mechanisms of polymer degradation and erosion. Biomaterials. 1996:17:103-14

35. Smith DC. The cleansing of dentures. Dent Pract Dent Rec. 1966;17(2):39-43.

36. Parker S, Riggs PD, Braden M, Kalachandra S, Taylor DF. Water uptake of soft lining materials from osmotic solutions. J Dent. 1997;25(3-4):297-304.

37. Yap AUJ, Lim LY, Yang TY, Ali A, Chung SM. Influence of dietary solvents on strength of nanofill and ormocer composites. Oper Dent. 2005;30(1):129-33.

38. Davalloo R, Tavangar M, Darabi F, PourhabibiZ, Alamouti NA. The surface hardness value of a light cured hybrid composite resin after 12 hours immersion in three alcohol-free mouthwashes. J Dentomaxillofacial Radiol, Pathol and Surg. 2013;2(4):1-6.

39. Lee SY, Huang HM, Lin CY, Shih YH. Leached components form dental composites in oral simulating fluids and the resultant composite strength. J Oral Rehabil. 1998;25(8):575-88.

40. Geurtsen W, Leyhausen G, Garcia-Godoy F.Effect of storage media on the fluoride release and surface microhardness of four polyacid-modified composite resins (compomers). Dent Mater. 1999;15(3):196-201.

\section{Dr.Dt. Emre Yilmaz}

\section{(Corresponding address)}

Ankara University

Faculty of Dentistry, Department of Restorative Dentistry, Ankara, Turkey

Emniyet Mh., İncitaş Sk., Sabancı Kız Yurdu Karşısı, 06560 Yenimahalle/Ankara

Date submitted: 2020 Jun 03

Email: emre06dt@gmail.com 